\title{
The Impact of Nonlocal Ammonia on Submicron Particulate Matter and Visibility Degradation in Urban Shanghai
}

\author{
Roeland Cornelis Jansen, Jianmin Chen, and Yunjie Hu \\ Shanghai Key Laboratory of Atmospheric Particle Pollution and Prevention, \\ Department of Environmental Science \& Engineering, Fudan University, Shanghai 200433, China
}

Correspondence should be addressed to Jianmin Chen; jmchen@fudan.edu.cn

Received 22 April 2014; Revised 10 June 2014; Accepted 10 June 2014; Published 5 August 2014

Academic Editor: Isidro A. Pérez

Copyright (C) 2014 Roeland Cornelis Jansen et al. This is an open access article distributed under the Creative Commons Attribution License, which permits unrestricted use, distribution, and reproduction in any medium, provided the original work is properly cited.

To study the role of submicron particulate matter on visibility degradation in Shanghai, mass concentrations of $\mathrm{PM}_{1}$, secondary inorganic aerosol (SIA) in $\mathrm{PM}_{1}$, and SIA precursor gasses were on-line monitored during a 4-week intensive campaign in December 2012. During the campaign, 8 haze periods were identified when on average $\mathrm{PM}_{1}$ mass increased to $62.1 \pm 25.6 \mu \mathrm{g} / \mathrm{m}^{3} \mathrm{compared}$ to $30.7 \pm 17.1 \mu \mathrm{g} / \mathrm{m}^{3}$ during clear weather periods. The sum of SIA in $\mathrm{PM}_{1}$ increased in mass concentration during the haze from $14.9 \pm$ $7.4 \mu \mathrm{g} / \mathrm{m}^{3}$ during clear periods to $29.7 \pm 10.7 \mu \mathrm{g} / \mathrm{m}^{3}$ during the haze periods. Correlation coefficients $\left(R^{2}\right)$ of the visibility as function of mass concentrations of SIA species in $\mathrm{PM}_{1}$ show negative exponential relations implying the importance of the SIA species in visibility reduction. The important role of ammonia in SIA formation is recognized and demonstrated. Generally, ammonium neutralizes sulfate and nitrate and the molar equivalent ratio of ammonium versus the sum of sulfate and nitrate increases during the haze episodes. Air mass backward trajectories introducing the haze periods show the impact of nonlocal ammonia on visibility degradation in Shanghai.

\section{Introduction}

The elevated concentrations of haze responsible air pollutants have an adverse impact on human health and the environment $[1,2]$ and concerns about the adverse effects have led to studies focusing on trends and chemistry of haze episodes in urban China. The megacity Shanghai (24.15 million inhabitants) is located in the Yangtze River Delta (YRD), a cluster of (mega)cities at the east coast of China. The YRD has become of increasing interest to anthropogenic emission studies [3-5] due to large-scale industrial and agricultural activities needed to meet the energy and food demand of the large population. Shanghai has been subject of studies to demonstrate consequences of its urbanization and visibility degradation due to air pollution is one of these consequences [6-9]. In urban areas, elevated concentrations of air pollutants may lead to periods of haze $[10,11]$ and in Shanghai the phenomenon of haze has become a regular happening $[6,12]$.
Of the air pollutants, atmospheric aerosol (or particulate matter $\mathrm{PM}$ ) is mainly responsible for the visibility degradation due to aerosol light scattering [13]. The submicron aerosol size range (described as $\mathrm{PM}_{1}$ where the aerosol aerodynamic diameter is equal or less than $1.0 \mu \mathrm{m}$ ) is highly efficient in scattering of light [2]. Chemically, this size fraction comprises a large mass of secondary inorganic aerosol (SIA) species ammonium $\left(\mathrm{NH}_{4}{ }^{+}\right)$, nitrate $\left(\mathrm{NO}_{3}{ }^{-}\right)$, sulfate $\left(\mathrm{SO}_{4}{ }^{2-}\right)$, and chloride $\left(\mathrm{Cl}^{-}\right)$[14]. Huang et al. [15] report a mass fraction of SIA in $\mathrm{PM}_{1}$ of $64.4 \%$ in Shanghai. The contribution of the particle's SIA fraction in visibility reduction has been studied and concerns mainly scattering of radiation by particulate sulfate and nitrate [16-19]. Moreover SIA species are highly hygroscopic causing increase in the water content of the particles, which enhances the scattering of light [20]. Therefore SIA species have become subject to aerosol studies related to visibility degradation $[18,21-$ 23]. Concentrations of ammonium, nitrate, and sulfate are parameters in models to calculate visibility. The Community 
multiscale air quality model (CMAQ) is developed by the USEPA and applied to simulate air quality in North China [24] and to indicate visibility using mass concentrations of SIA species (between organic carbon and elemental carbon) [25-28]. The CMAQ system is used to study formation and transport of air pollutants [29] and has been applied in Asia in modeling studies of air pollutants [24, 30-34]. With the large mass fraction of SIA in $\mathrm{PM}_{1}$ and the scattering efficiency of SIA species, it seems crucial to relate the role of $\mathrm{PM}_{1}$ to visibility degradation.

Ammonia $\left(\mathrm{NH}_{3}\right)$ is the main alkaline gas in the atmosphere [35] and large-scale emissions of ammonia are observed in the YRD $[3,4]$. The emission of ammonia from mainly agriculture activities (livestock feeding and fertilizer synthesis) has increased dramatically to meet the food demand of the increasing population of the YRD and the increase in ammonia emission is expected to continue. Ammonia neutralizes acidic trace gasses resulting in secondary aerosol containing the ammonium-ion $\left(\mathrm{NH}_{4}{ }^{+}\right)[35$, 36]. Only ammonia is emitted from the biosphere to the atmosphere; all atmospheric ammonium used to be ammonia [37]. The thermodynamically favored reaction is the neutralization of sulfuric acid $\left(\mathrm{H}_{2} \mathrm{SO}_{4}\right)$, which is a product of the oxidation of $\mathrm{SO}_{2}$, yielding particulate ammonium sulfate $\left(\mathrm{NH}_{4}\right)_{2} \mathrm{SO}_{4}(\mathrm{l})$ [38-41]. The reaction between ammonia and nitric acid $\left(\mathrm{HNO}_{3}\right)$, which is a product of the oxidation of $\mathrm{NO}_{x}$, forming particulate ammonium nitrate $\left(\mathrm{NH}_{4} \mathrm{NO}_{3}(\mathrm{~s}, \mathrm{l})\right)$ $[42,43]$ follows. Hydrochloric acid $(\mathrm{HCl})$ contributes to particulate ammonium due to homogeneous reaction with ammonia [44] but atmospheric concentrations of $\mathrm{HCl}$ are usually low. Moreover, mass of particulate chloride usually correlates with sodium indicating that the $\mathrm{Cl}^{-}$is not from the homogeneous reaction of hydrochloric acid with ammonia but originates from sea salt. Due to the role of ammonia in sulfate and nitrate formation and the role of the later species in visibility degradation in urban area, the important role of ammonia is recognized. Erisman and Schaap [45] show the importance of reducing ammonia emissions to achieve lower secondary aerosol concentrations in Europe. Barthelmie and Pryor [46] propose that transport of urban emissions of $\mathrm{NO}_{x}$ and $\mathrm{SO}_{2}$ over agricultural area with ammonia emissions results in ammonium nitrate and ammonium sulfate formation and consequently higher mass concentrations of PM in agricultural area. Shanghai is ammonia deficient $[42,47]$ while $\mathrm{NO}_{x}$ and $\mathrm{SO}_{2}$ are present due to large-scale emissions of traffic and industry. Shanghai is surrounded by agricultural areas where crops are grown and animal farms are situated $[3,4]$. Hence it is likely that transport of ammonia from nonlocal sources outside the city of Shanghai is responsible for the elevated concentrations of ammonium, nitrate, and sulfate in Shanghai.

Here we present hourly mass concentrations of SIA species ammonium, nitrate, and sulfate in $\mathrm{PM}_{1}$ in Shanghai for 4 weeks of intensive measurements in December 2012. The importance of the presence of ammonium during periods of visibility degradation is demonstrated. To demonstrate that the precursor gas of ammonium, ammonia, is coming from nonlocal sources, backward trajectories of air masses arriving at the sampling site were computed using the hybrid singleparticle Lagrangian integrated trajectory model $4[48,49]$.

\section{Methodology}

2.1. Location of the Sampling Site and Time of Sampling. Sampling took place in the northeast of Shanghai $\left(31.3^{\circ} \mathrm{N}\right.$, $121.5^{\circ} \mathrm{E}$ ) (Figure 1 ) on the roof ( $20 \mathrm{~m}$ high) of the 4 th Teaching Building on the campus of Fudan University. The area around the campus is representative for an urban area due to residential, traffic, and construction activities. Measurements were performed between December 1 and 31, 2012.

\subsection{On-Line $P M_{1}$ Inorganic Composition, Related Trace Gas} Concentrations and $P M_{1}$ Mass Concentrations. The on-line MARGA ADI 2080 (Applikon-ECN, The Netherlands) was used to acquire hourly concentrations of particulate sodium $\left(\mathrm{Na}^{+}\right)$, ammonium $\left(\mathrm{NH}_{4}^{+}\right)$, potassium $\left(\mathrm{K}^{+}\right)$, calcium $\left(\mathrm{Ca}^{2+}\right)$, magnesium $\left(\mathrm{Mg}^{2+}\right)$, chloride $\left(\mathrm{Cl}^{-}\right)$, nitrate $\left(\mathrm{NO}_{3}^{-}\right)$, and sulfate $\left(\mathrm{SO}_{4}{ }^{2-}\right)$ and mixing ratios of gas species ammonia $\left(\mathrm{NH}_{3}\right)$, nitric acid $\left(\mathrm{HNO}_{3}\right)$, nitrous acid $\left(\mathrm{HNO}_{2}\right)$, hydrochloric acid $(\mathrm{HCl})$, and sulfur dioxide $\left(\mathrm{SO}_{2}\right)$. MARGA sampled $1 \mathrm{~m}^{3}$ of air per hour by means of a Teflon-coated $\mathrm{PM}_{1}$ cyclone (URG Co.) situated at the inlet of the instrument. The airflow is volumetric constant and adjusted by a mass flow control system (Bronkhorst HIGH-TECH NL) adjusted according to ambient pressure and temperature. Air temperature inside the measurement station was held constant at $20^{\circ} \mathrm{C}$. Detailed working of MARGA for aerosol and gas measurements can be found elsewhere [50-53] and is only briefly described here. MARGA uses a wet rotating denuder for gas sampling where gases are absorbed on the wall of a liquid coated annulus. Particles make it through this annulus and arrive in the steam-jet-aerosol-collector (SJAC) where a supersaturated environment of steam is created. Steam condenses on the particles and droplets are formed which are collected. Both samples streams (gas and aerosol) are collected by means of a syringe system and analyzed by ion-chromatography. Ammonium salts have been demonstrated to evaporate back to ammonia in the steam chamber of the particle-intoliquid-sampler (PILS) and consequently particulate ammonium concentrations are underestimated between 5 and 20\% according to Sorooshian et al., 2006 [54]. Similar studies have not been reported for the MARGA; however, we cannot rule out that ammonium is underestimated due to evaporation in the SJAC. Trebs et al. [55] estimate aerosol loss of $\leq 3 \%$ for $\mathrm{PM}_{2.5}$ aerosol in MARGA due to nonisokinetic sampling. For gas species sampled by MARGA a "worst case scenario" is calculated using $\mathrm{HNO}_{3}$ (considered the most difficult gas to sample) and a loss of $\leq 15 \%$ is reported.

$\mathrm{PM}_{1}$ mass concentrations were obtained from the synchronized hybrid ambient real-time particulate monitor (SHARP Model 5030, Thermo Fisher Scientific). The SHARP is equipped with the intelligent moisture control system (IMR) to regulate humidity levels eliminating moisture effects on mass concentrations that are obtained. The $\mathrm{PM}_{1}$ mass 

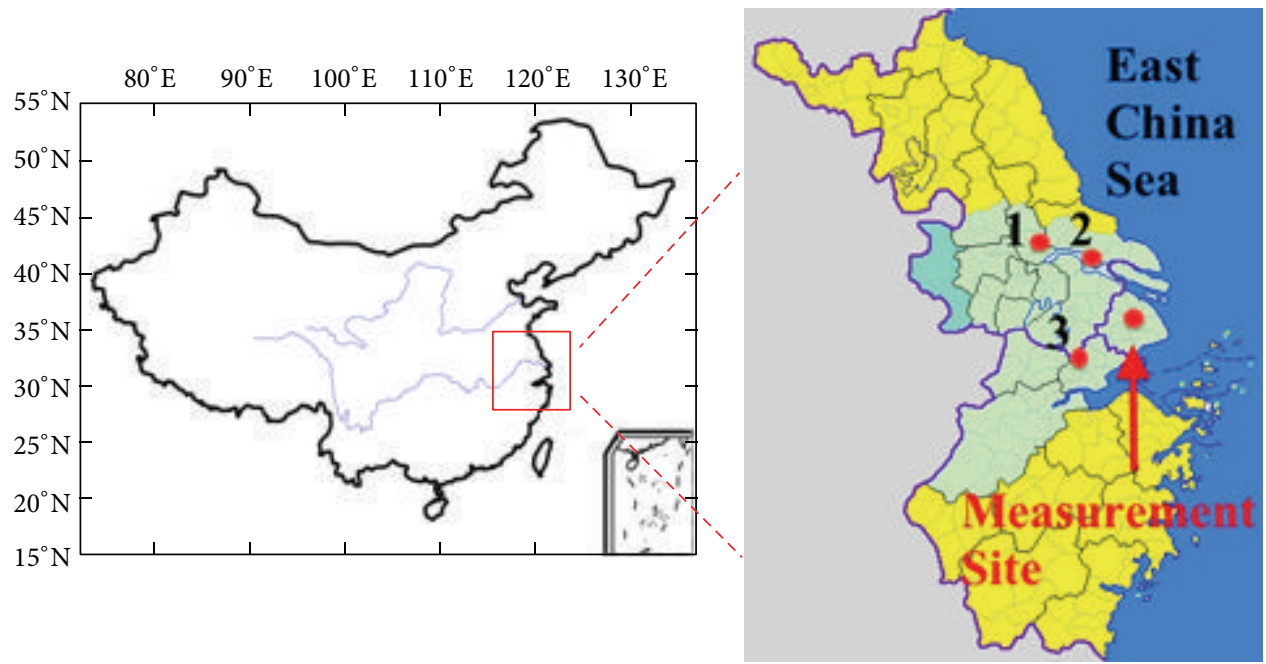

FIGURE 1: Location of the measurement site in Shanghai. Locations 1, 2, and 3 are Yangzhou (NW of Shanghai), Nantong (NNW of Shanghai), and Jiaxing (SW of Shanghai).

TABLE 1: Recoveries of the instruments during the measurement period.

\begin{tabular}{lcc}
\hline Instrument & $\begin{array}{c}\text { Valid data } \\
(\mathrm{h})\end{array}$ & $\begin{array}{c}\text { Missing } \\
\text { data }(\mathrm{h})\end{array}$ \\
\hline MARGA (ADI 2080) & 660 & 84 \\
PM $_{1}$ monitor (SHARP 5030) & 744 & 0 \\
Visibility sensor (Belfort 5000) & 743 & 1 \\
Automatic weather station (Hydro Met) & 744 & 0 \\
\hline
\end{tabular}

concentrations in this study are considered dry mass concentration such as the MARGA results. A Teflon-coated $\mathrm{PM}_{1}$ cyclone (URG Co.) is situated at the inlet of the instrument.

2.3. Meteorological Data. Visibility was measured using a Belfort Model 5000 sensor. Relative humidity, ambient temperature, ambient pressure, wind speed, and wind direction were monitored with an automatic weather station from Vaisala (HydroMet).

Data recoveries of the instruments are shown in Table 1. The missing data of the MARGA (11\%) was due to instrument failure and maintenance.

2.4. Air Trajectory Analysis. To study the aerosol transport characteristics, 3-day air mass backward trajectories were computed using the NOAA hybrid single-particle lagrangian integrated trajectory (HYSPLIT) model 4 from http://www.arl.noaa.gov/ready/hysplit4.html [48, 49]. Air masses of two arrival air mass altitudes, namely, 500 and 1000 meters, were used, which represent the average mixed layer height in Shanghai $[8,56,57]$.

\section{Results and Discussion}

3.1. Classification of the Visibility Degradation Episodes with Mass Concentrations of Pollutants. In previous visibility degradation studies, haze episodes are defined as a continuous period of longer than 4 hours when the visibility is below $10 \mathrm{~km}$ while the $\mathrm{RH}$ value does not exceed 90\% [7, $58,59]$. Low visibility weather can also be caused by high $\mathrm{RH}(\geq 90 \%)$ and is referred to as foggy weather, where the decrease in visibility is in a large extent caused by the amount of water in the air. Data obtained during foggy episodes $(\mathrm{RH} \geq 90 \%)$ as well as data obtained during periods of precipitation are not subject of study here. Time series of the visibility, $\mathrm{RH}$, precipitation, and haze episodes are shown in Figure 2(a). According to the definition of haze described above, 8 haze episodes were identified. The time series of mass concentrations of the particulate species and SIA precursor gasses are shown in Figures 2(b) and 2(c). Details of the events including start and end time, average mass concentrations of SIA species, $\mathrm{PM}_{1}$ mass concentrations, and SIA precursor gasses are shown in Table 2. Also average data is provided for all haze periods as well as for the foggy periods and clear periods (visibility $>10 \mathrm{~km}$ ). We will focus on the periods where the visibility is around or less than $10 \mathrm{~km}$ while the $\mathrm{RH}$ does not exceed $90 \%$.

The hourly $\mathrm{PM}_{1}$ mass concentrations during the 31 days of measurements averaged $31.9 \pm 21.4 \mu \mathrm{g} / \mathrm{m}^{3}$ and ranged from 3.3 to $130.6 \mu \mathrm{g} / \mathrm{m}^{3}$. During the measurement period the average hourly mass concentrations of SIA species in $\mathrm{PM}_{1}$ were as follows: $\left[\mathrm{NH}_{4}{ }^{+}\right]$averaged $4.1 \pm 2.6 \mu \mathrm{g} / \mathrm{m}^{3}$, $\left[\mathrm{SO}_{4}{ }^{2-}\right]$ averaged $6.0 \pm 2.8 \mu \mathrm{g} / \mathrm{m}^{3}$, and $\left[\mathrm{NO}_{3}{ }^{-}\right]$averaged $5.4 \pm$ $4.9 \mu \mathrm{g} / \mathrm{m}^{3}$. The sum of these SIA species averaged $15.5 \pm$ $9.8 \mu \mathrm{g} / \mathrm{m}^{3}$ which accounted for $51.1 \pm 12.9 \%$ of the $\mathrm{PM}_{1}$ mass. Sulfate is the most abundant component of the SIA species in $\mathrm{PM}_{1}$ (22.5 mass\%), followed by nitrate (15.1 mass\%) and ammonium (13.3 mass\%). Sulfate contribution is lower compared to Huang et al. [15] who report a mass fraction in $\mathrm{PM}_{1}$ in Shanghai of $33.3 \%$, while values for nitrate $(16.3 \%)$ and ammonium (13.4\%) are similar.

The mass concentrations of $\mathrm{PM}_{1}$ increase significantly during the 8 periods of haze compared to clear weather 
TABLE 2: Start and end time, visibility, RH, and average concentrations of aerosol and gas species during the haze, foggy, and clear weather periods.

\begin{tabular}{|c|c|c|c|c|c|c|c|c|c|}
\hline \multirow{2}{*}{ Start and end time } & \multirow{2}{*}{$\begin{array}{c}\text { Vis. } \\
(\mathrm{km} .)\end{array}$} & \multirow{2}{*}{$\begin{array}{l}\text { RH } \\
(\%)\end{array}$} & \multicolumn{3}{|c|}{ Aerosol species $\left(\mu \mathrm{g} / \mathrm{m}^{3}\right)$} & \multirow{2}{*}{$\mathrm{PM}_{1}$} & \multicolumn{3}{|c|}{ Gas species $\left(\mu \mathrm{g} / \mathrm{m}^{3}\right)$} \\
\hline & & & $\mathrm{NH}_{4}^{+}$ & $\mathrm{SO}_{4}{ }^{2-}$ & $\mathrm{NO}_{3}^{-}$ & & $\mathrm{NH}_{3}$ & $\mathrm{SO}_{2}$ & $\mathrm{HNO}_{3}$ \\
\hline (1) $3 / 1212.00-3 / 1221.00$ & 8.4 & 64 & 6.4 & 9.7 & 8.4 & 48.6 & 2.5 & 20.0 & 0.7 \\
\hline (2) $7 / 1222.00-9 / 1201.00$ & 7.6 & 56 & 11.0 & 10.9 & 19.3 & 93.2 & 5.1 & 47.4 & 2.0 \\
\hline (3) $14 / 1212.00-15 / 1200.00$ & 6.4 & 76 & 8.2 & 10.5 & 9.9 & 65.0 & 11.8 & 18.9 & 0.9 \\
\hline (4) $16 / 1215.00-17 / 1207.00$ & 6.6 & 83 & 4.9 & 8.5 & 4.8 & 31.4 & 9.5 & 2.9 & 0.4 \\
\hline (5) $21 / 1209.00-21 / 1218.00$ & 5.4 & 87 & 4.6 & 7.4 & 4.2 & 44.7 & 3.7 & 3.1 & 0.5 \\
\hline (6) $22 / 1209.00-22 / 1214.00$ & 7.1 & 74 & 7.9 & 12.6 & 10.6 & 54.3 & 3.2 & 15.9 & 0.7 \\
\hline (7) $23 / 1207.00-23 / 1216.00$ & 9.2 & 57 & 9.3 & 12.6 & 14.9 & 65.7 & 1.1 & 60.5 & 2.0 \\
\hline (8) $29 / 1223.00-30 / 1206.00$ & 6.7 & 81 & 5.5 & 7.9 & 8.4 & 48.0 & 1.7 & 8.9 & 0.8 \\
\hline Ave. "haze periods" (94 hours) & 7.2 & 70 & 7.9 & 10.1 & 11.7 & 62.1 & 5.4 & 26.9 & 1.4 \\
\hline Ave. "foggy" periods (40 hours) & 5.4 & 94 & 2.9 & 5.2 & 2.5 & 24.2 & 4.7 & 3.2 & 0.4 \\
\hline Ave. "clear" periods (483 hours) & 25.6 & 59 & 3.9 & 5.8 & 5.2 & 30.7 & 3.3 & 23.1 & 0.9 \\
\hline
\end{tabular}

periods. An average of $30.7 \pm 17.1 \mu \mathrm{g} / \mathrm{m}^{3}$ during clear periods is measured and an average of $62.1 \pm 25.6 \mu \mathrm{g} / \mathrm{m}^{3}$ during the haze periods is measured. The sum of SIA species shows a similar trend and increased from an average of $14.9 \pm$ $7.4 \mu \mathrm{g} / \mathrm{m}^{3}$ during clear periods to $29.7 \pm 10.7 \mu \mathrm{g} / \mathrm{m}^{3}$ during the haze periods. This means the mass contribution of SIA to $\mathrm{PM}_{1}$ during clear periods averaged $51.0 \pm 12.3 \%$ while the mass contribution during the haze averaged $48.2 \pm 7.9 \%$. The results imply a relation of $\mathrm{PM}_{1}$ and SIA species with the visibility degradation that is observed.

3.2. Correlations between Visibility and Mass Concentrations of $\mathrm{PM}_{1}$ Species. The correlations between visibility and $\mathrm{PM}_{1}$ mass concentrations of SIA species during clear and haze periods are explored to demonstrate the importance of the SIA species in visibility reduction. The visibility decreases exponentially with increase of $\mathrm{PM}_{1}$ mass (Figure 3(a)) and the same trend is observed for SIA species (Figures 3(b), 3(c), and $3(\mathrm{~d}))$. The correlation coefficients $\left(R^{2}\right)$ of the visibility as function of the concentrations are in the order of $\mathrm{PM}_{1}$ $(0.56)>$ ammonium $(0.52)>$ sulfate $(0.41)>$ nitrate $(0.39)$. Note that the upper limit of the visibility instrument is $50 \mathrm{~km}$, and the data obtained for mass concentrations during these measurements are not used for the correlation coefficients. Although correlation coefficients are low, it is clear that there is a relation between mass concentrations of $\mathrm{PM}_{1}$ solely and SIA mass concentrations in $\mathrm{PM}_{1}$ and visibility degradation. Now we demonstrated the importance of $\mathrm{PM}_{1}$ and SIA in $\mathrm{PM}_{1}$ in visibility measurements and we can focus on time series of the species during decreased visibility. For that the molar equivalent ratio of ammonium versus the sum of sulfate and nitrate and the difference between the expected and observed ammonium in $\mathrm{PM}_{1}$ are used.

3.3. Molar Equivalent Ratio of Ammonium to the Sum of Sulfate and Nitrate. The ionic balance,

$$
\frac{\left[\mathrm{NH}_{4}{ }^{+}\right] / 18}{\left(\left[\mathrm{SO}_{4}{ }^{2-}\right] / 48\right)+\left(\left[\mathrm{NO}_{3}^{-}\right] / 62\right)}
$$

where the species are converted in molar concentrations $\left(\mathrm{mol} / \mathrm{m}^{3}\right)$, has been applied to study the amount of sulfate and nitrate that has been neutralized by ammonium $[42,60]$. Numbers by Pathak et al. [42] for a number of worldwide locations show that particles in urban area are neutralized by ammonium when sulfate and nitrate are low but particles become acidic when ammonium is no longer able to neutralize high mass concentrations of the acidic species sulfate and nitrate. Time series for the molar equivalent ratio of ammonium is shown in Figure 4.

We can now "predict" the concentration of ammonium in $\mathrm{PM}_{1}$ assuming that all ammonium is coupled to sulfate and nitrate. For that we apply the following:

$$
\left[\mathrm{NH}_{4}{ }^{+}\right]_{\mathrm{PRED}}=18 *\left(\left(\frac{\left[\mathrm{SO}_{4}{ }^{--}\right]}{48}\right)+\left(\frac{\left[\mathrm{NO}_{3}^{-}\right]}{62}\right)\right)
$$

Figure 5 shows the correlation between $\left[\mathrm{NH}_{4}{ }^{+}\right]_{\mathrm{PRED}}$ and the actual measured $\mathrm{NH}_{4}{ }^{+}\left(\left[\mathrm{NH}_{4}{ }^{+}\right]_{\text {MEAS }}\right)$, for the entire study period. Data shows very good agreement between the values $\left(R^{2}=0.97\right)$. The slope of the regression shows an offset of 0.12 which means that, on average, 12 mass $\% \mathrm{NH}_{4}{ }^{+}$PRED is underestimated. This can be explained by ammonium bound to species such as chloride and bisulfate which are not in (2). Contrarily, nitrate and sulfate in (2) may be bound to basic species such as amines $[61,62]$. Amines, especially diethyl amine, may compete with ammonia for the acidic species forming amine-salts. Sorooshian et al. [61] report amines concentrations around $\sim 20 \%$ of that of ammonium near a bovine source and report that nitrate correlates with amine in $\mathrm{PM}_{1}$. For (2) this would lead to overestimation of $\mathrm{NH}_{4}{ }^{+}$PRED which means even more than the 12 mass\% of the measured ammonium is bound to chloride and bisulfate.

Table 3 shows the results of (1), the predicted $\mathrm{NH}_{4}^{+}$ concentrations $\left(\left[\mathrm{NH}_{4}{ }^{+}\right]_{\mathrm{PRED}}\right)$, the measured values of $\mathrm{NH}_{4}{ }^{+}\left(\left[\mathrm{NH}_{4}{ }^{+}\right]_{\text {MEAS }}\right)$, and the differences between predicted and measured $\mathrm{NH}_{4}^{+}$.

On average we observe a value of $1.05 \pm 0.11$ for (1) during the entire measurement period indicating that there is sufficient ammonium to neutralize nitrate and sulfate and 


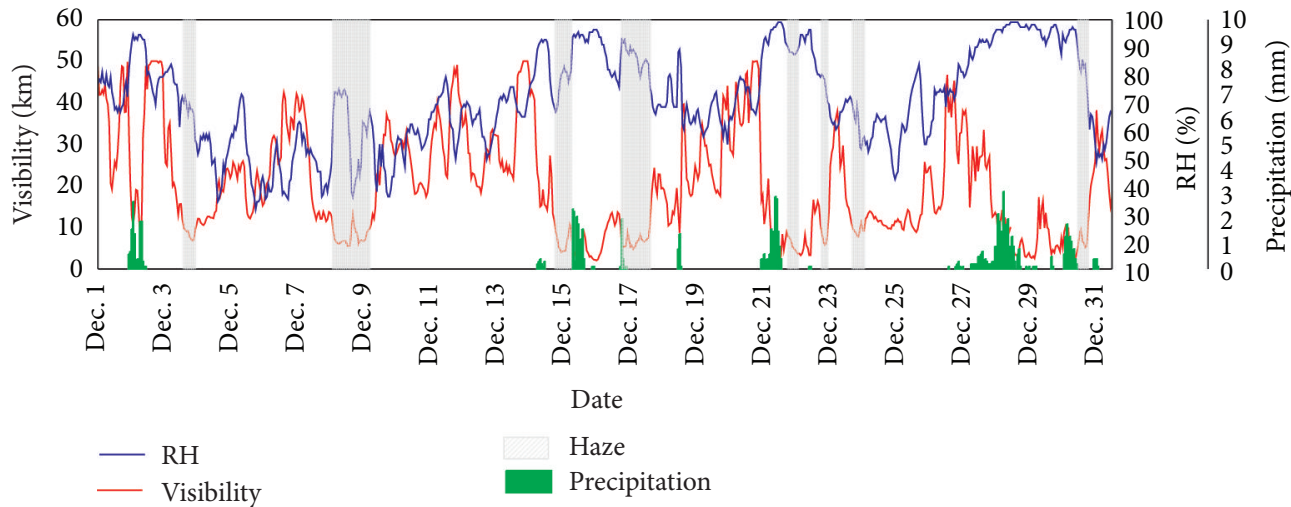

(a)

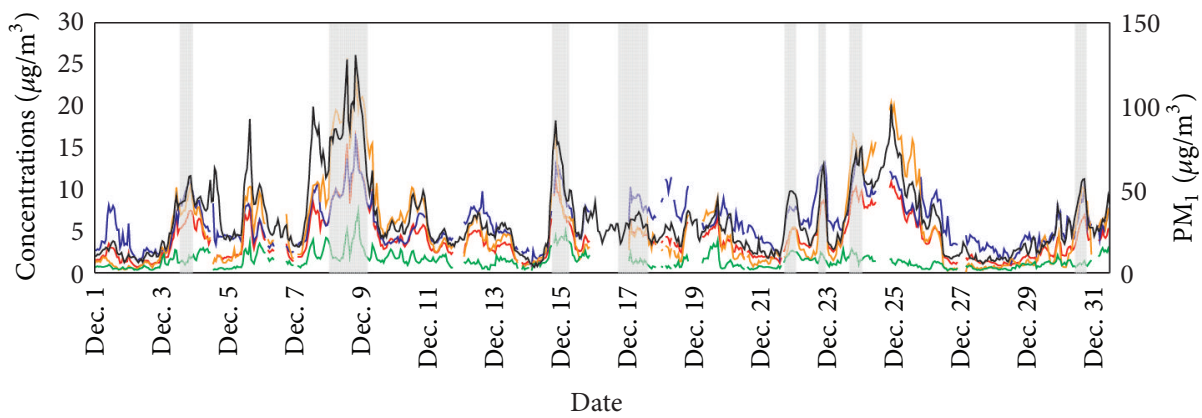

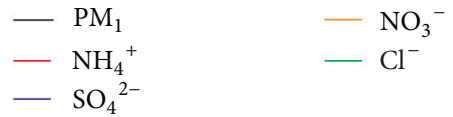

(b)

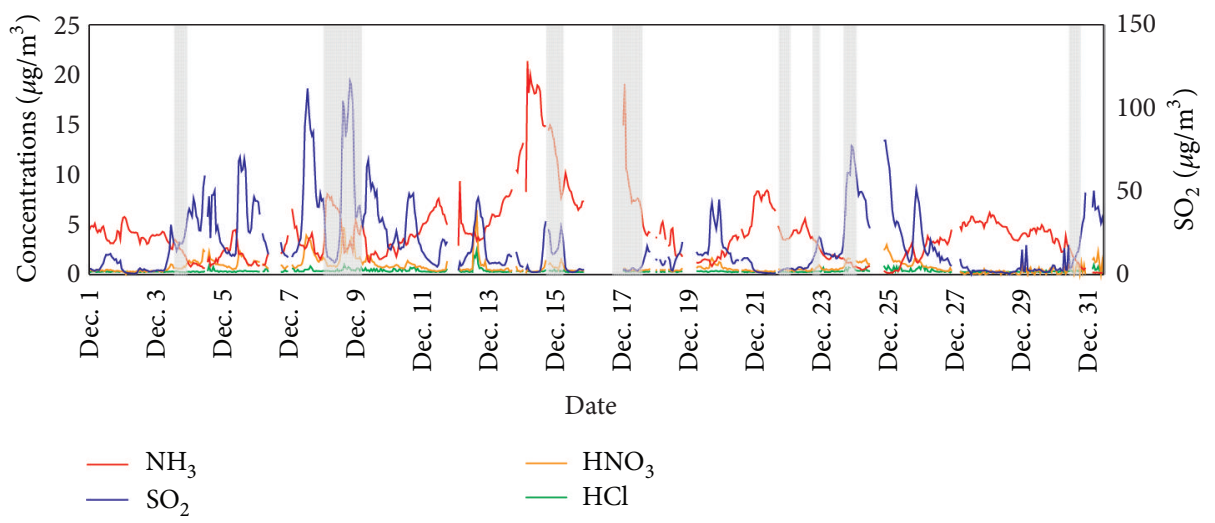

(c)

FIGURE 2: Time series of (a) visibility $(\mathrm{km}), \mathrm{RH}(\%)$, and precipitation $(\mathrm{mm} / \mathrm{h}),(\mathrm{b})$ mass concentration $\left(\mu \mathrm{g} / \mathrm{m}^{3}\right)$ of $\mathrm{PM}_{1}$ and SIA species $\left(\mathrm{NH}_{4}{ }^{+}, \mathrm{SO}_{4}{ }^{2-}, \mathrm{NO}_{3}{ }^{-}\right.$, and $\left.\mathrm{Cl}^{-}\right)$, and (c) mass concentration $\left(\mu \mathrm{g} / \mathrm{m}^{3}\right)$ of precursor gasses $\left(\mathrm{NH}_{3}, \mathrm{HNO}_{3}, \mathrm{SO}_{2}\right.$, and $\left.\mathrm{HCl}\right)$ during the study period (December 1-31, 2012) in Shanghai. Gray hatched frames represent the 8 haze episodes.

$\mathrm{PM}_{1}$ contains $5 \mathrm{~mol} \%$ more ammonium than the sum of sulfate and nitrate. Values for (1) during the haze (1.10 \pm 0.08$)$ surpassed values of foggy $(1.07 \pm 0.08)$ and clear weather $(1.05 \pm 0.11)$ periods indicating excess ammonium during the haze periods. For the haze periods 2,3 , and 5 the equimolar balance increases significantly which can at least partly be explained by the elevated concentrations of $\mathrm{Cl}^{-}$observed
(Figure 2(b)), which may come from organic halides from local industrial sources [42]. The equimolar ratio for haze periods 6, 7, and 8 is far below average and from Figure 2(b) it can be seen that ammonium stays behind sulfate and nitrate concentrations. Periods when ammonia and/or ammonium are high in absolute value (periods 2, 3, 4, and 7 in Table 2) and periods where ammonium surpassed molar equivalent 


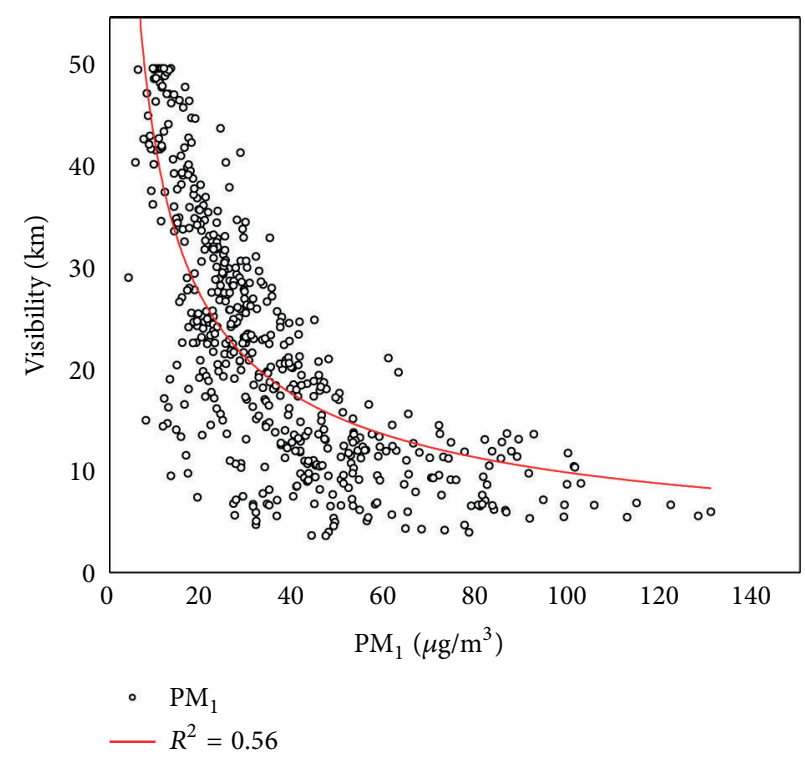

(a)

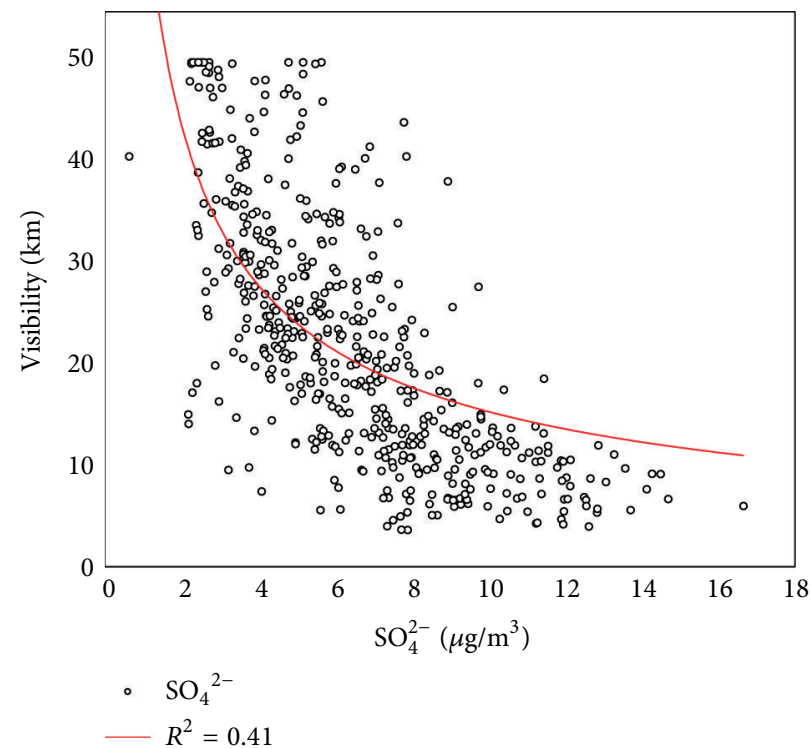

(c)

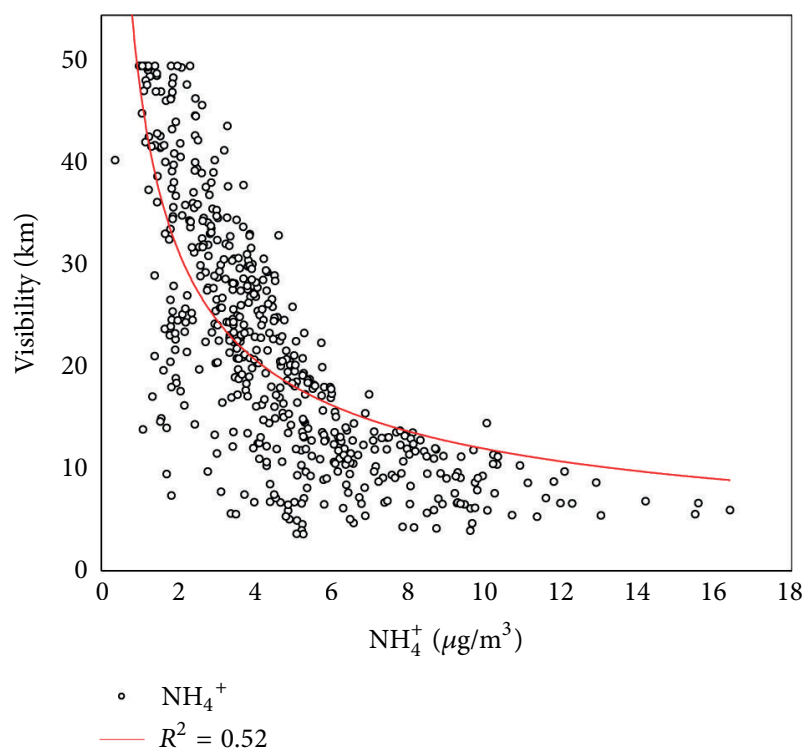

(b)

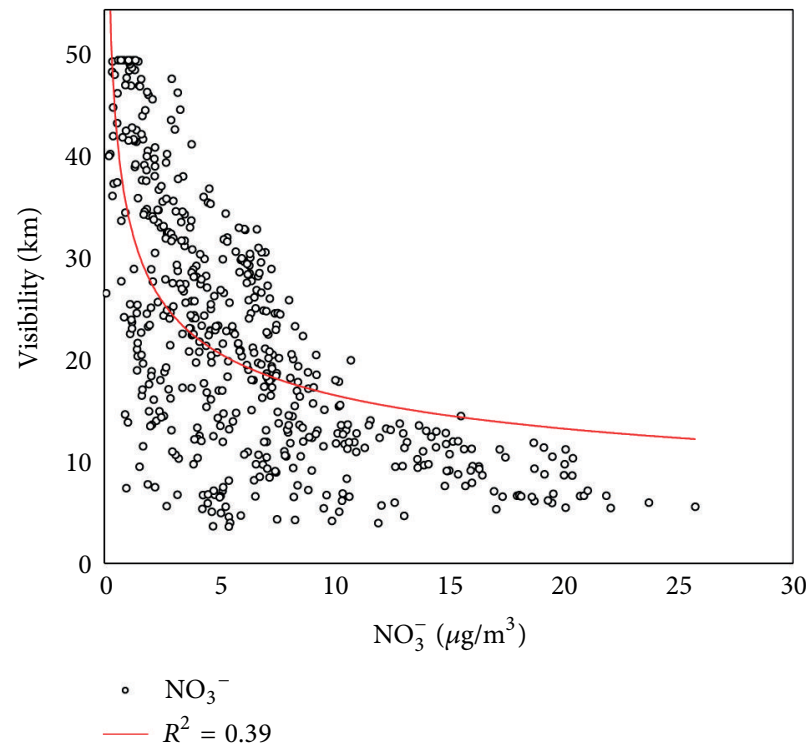

(d)

Figure 3: The relationship of particulate species concentration $\left(\mu \mathrm{g} / \mathrm{m}^{3}\right)$ and visibility (km) (a) $\mathrm{PM}_{1}$, (b) $\mathrm{NH}_{4}{ }^{+}$, (c) $\mathrm{SO}_{4}{ }^{2-}$, and (d) $\mathrm{NO}_{3}{ }^{-}$. Data for rain periods and $\mathrm{RH}>90 \%$ are left out. Data where vis. $>50 \mathrm{~km}$. (upper limit of the instrument) are shown but not used in the $R^{2}$ calculation.

values of the sum of sulfate and nitrate (periods 2, 3, and 5) raise interest and need further study.

3.4. The Transport of Nonlocal $\mathrm{NH}_{3}$ to the Measurement Site. Time series in Figure 2(b) together with the correlations shown in Figures 4 and 5 demonstrate that $\mathrm{NH}_{4}{ }^{+}, \mathrm{SO}_{4}{ }^{2-}$, and $\mathrm{NO}_{3}{ }^{-}$in $\mathrm{PM}_{1}$ follow similar trends. Figure 2(c) demonstrates most of the time $\mathrm{NH}_{3}$ concentrations show a different trend with $\mathrm{SO}_{2}\left(R^{2}=0.17\right)$ and $\mathrm{HNO}_{3}\left(R^{2}=0.07\right)$ and this indicates that $\mathrm{NH}_{3}$ is from a different source than $\mathrm{SO}_{2}$ and $\mathrm{HNO}_{3}$. Traffic and industry in Shanghai are responsible for elevated $\mathrm{NO}_{x}$ and $\mathrm{SO}_{2}[3,4]$, and $\mathrm{Li}$ et al. [3] show the numerous point sources of $\mathrm{NO}_{x}$ and $\mathrm{SO}_{2}$ emission by power plants and industrial activities in Shanghai, hence the assumption that $\mathrm{NH}_{3}$ is transported to the urban area where it reacts with $\mathrm{HNO}_{3}$ and $\mathrm{H}_{2} \mathrm{SO}_{4}$ to form the SIA species. Huang et al. [4] show the spatial allocation of air pollutants emissions with their concentrations over the YRD. For $\mathrm{NH}_{3}$ emission sources are Yangzhou (NW of Shanghai), Nantong (NNW of Shanghai), and Jiaxing (SW of Shanghai) (Figure 1). Figure 6 shows 72-hour air mass backward trajectories for all the haze periods to study the long-distance impact of ammonia on the visibility degradation. Air masses of two arrival altitudes, namely, 500 and 1000 meters, are employed. 


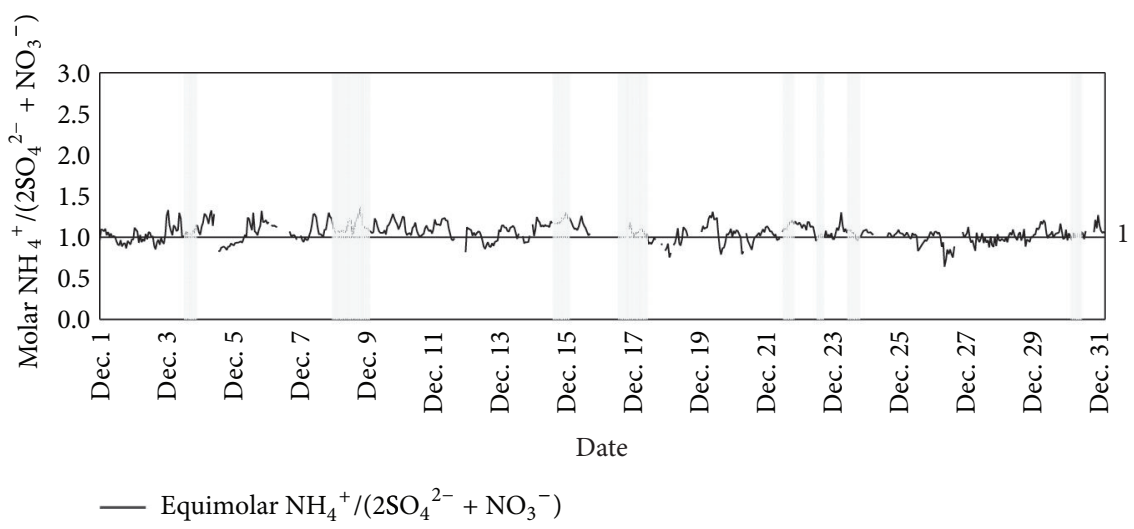

FIGURE 4: Time series of the molar equivalent ratio $\left[\mathrm{NH}_{4}{ }^{+}\right] /\left(\left[\mathrm{SO}_{4}{ }^{2-}\right]+\left[\mathrm{NO}_{3}{ }^{-}\right]\right)$during the study period.

TABLE 3: Average values for the molar equivalent ratio of ammonium to the sum of sulfate and nitrate (1), $\left[\mathrm{NH}_{4}{ }^{+}\right]_{\mathrm{PRED}},\left[\mathrm{NH}_{4}{ }^{+}\right]_{\mathrm{MEAS}}$, and the difference between the latter two during the haze, foggy, and clear weather periods.

\begin{tabular}{|c|c|c|c|c|}
\hline Start and end time & Equation (1) & $\begin{array}{l}\mathrm{NH}_{4}^{+} \text {PRED } \\
\left(\mu \mathrm{g} / \mathrm{m}^{3}\right)\end{array}$ & $\begin{array}{c}\mathrm{NH}_{4}^{+} \text {MEAS } \\
\left(\mu \mathrm{g} / \mathrm{m}^{3}\right)\end{array}$ & $\begin{array}{c}\mathrm{NH}_{4}^{+}{ }_{\text {MEAS }}-\mathrm{NH}_{4}^{+} \text {PRED } \\
\left(\mu \mathrm{g} / \mathrm{m}^{3}\right)\end{array}$ \\
\hline (1) $3 / 1212.00-3 / 1221.00$ & $1.06 \pm 0.04$ & 6.1 & 6.4 & 0.3 \\
\hline (2) $7 / 1222.00-9 / 1201.00$ & $1.13 \pm 0.08$ & 9.7 & 11.0 & 1.3 \\
\hline (3) $14 / 1212.00-15 / 1200.00$ & $1.21 \pm 0.04$ & 6.8 & 8.2 & 1.4 \\
\hline (4) $16 / 1215.00-17 / 1207.00$ & $1.07 \pm 0.04$ & 4.6 & 4.9 & 0.3 \\
\hline (5) $21 / 1209.00-21 / 1218.00$ & $1.15 \pm 0.04$ & 4.0 & 4.6 & 0.6 \\
\hline (6) $22 / 1209.00-22 / 1214.00$ & $1.01 \pm 0.02$ & 7.8 & 7.9 & 0.1 \\
\hline (7) $23 / 1207.00-23 / 1216.00$ & $1.03 \pm 0.05$ & 9.0 & 9.3 & 0.3 \\
\hline (8) $29 / 1223.00-30 / 1206.00$ & $1.02 \pm 0.03$ & 5.4 & 5.5 & 0.1 \\
\hline Ave. "haze periods" (94 hours) & $1.10 \pm 0.08$ & 7.2 & 7.9 & 0.7 \\
\hline Ave. "foggy" periods (40 hours) & $1.07 \pm 0.08$ & 2.7 & 2.9 & 0.2 \\
\hline Ave. "clear" periods (483 hours) & $1.05 \pm 0.11$ & 3.7 & 3.9 & 0.2 \\
\hline
\end{tabular}

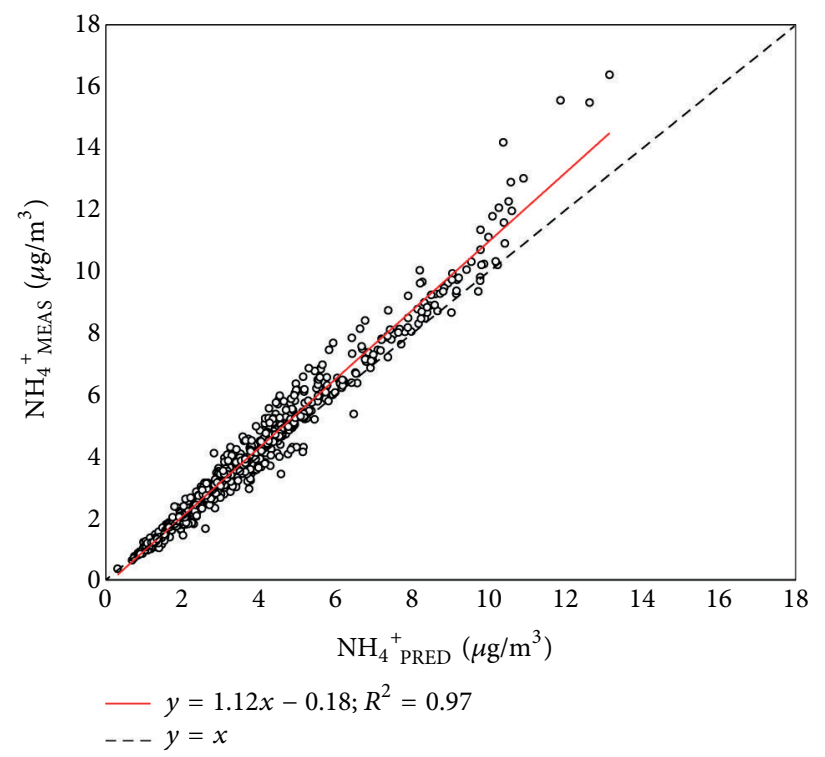

FIGURE 5: Linear correlation between the predicted amount of ammonium $\left(=\left[\mathrm{NH}_{4}{ }^{+}\right]_{\mathrm{PRED}}\right)$ and measured amount of ammonium $(=$ $\left.\left[\mathrm{NH}_{4}^{+}\right]_{\text {MEAS }}\right)$ for the entire study period $(n=660)$. 


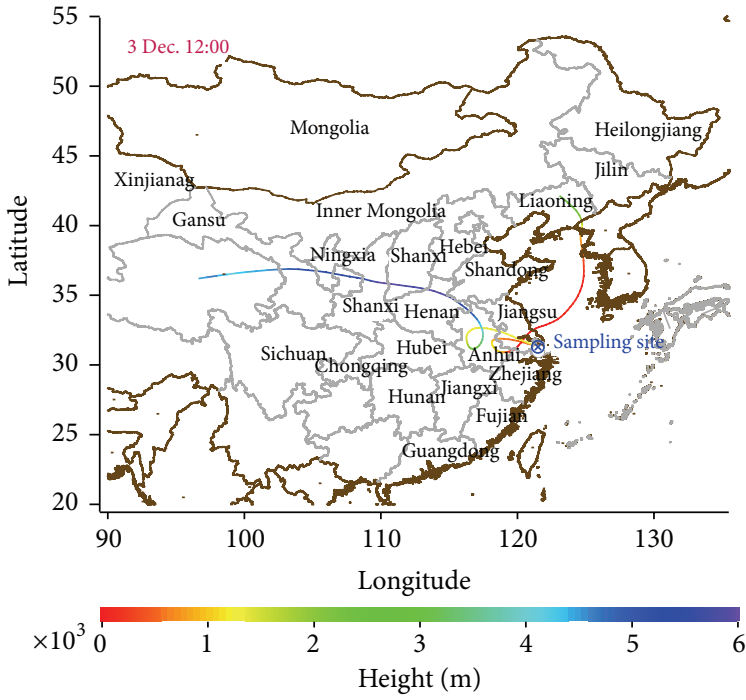

(a)

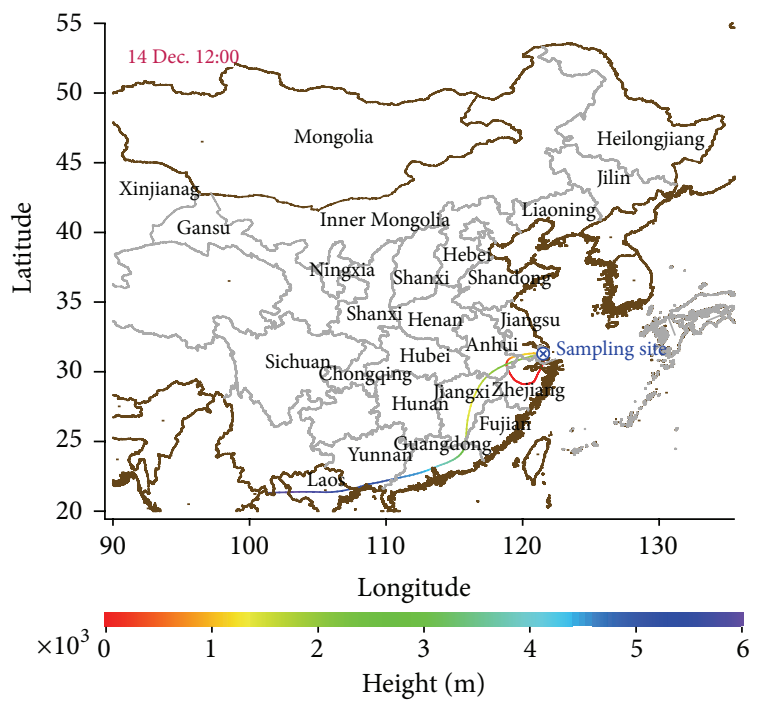

(c)

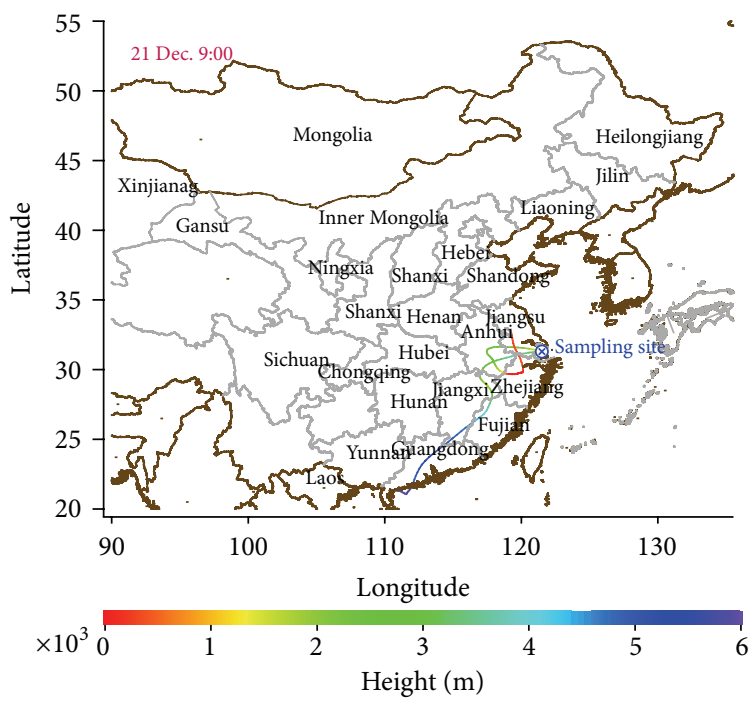

(e)

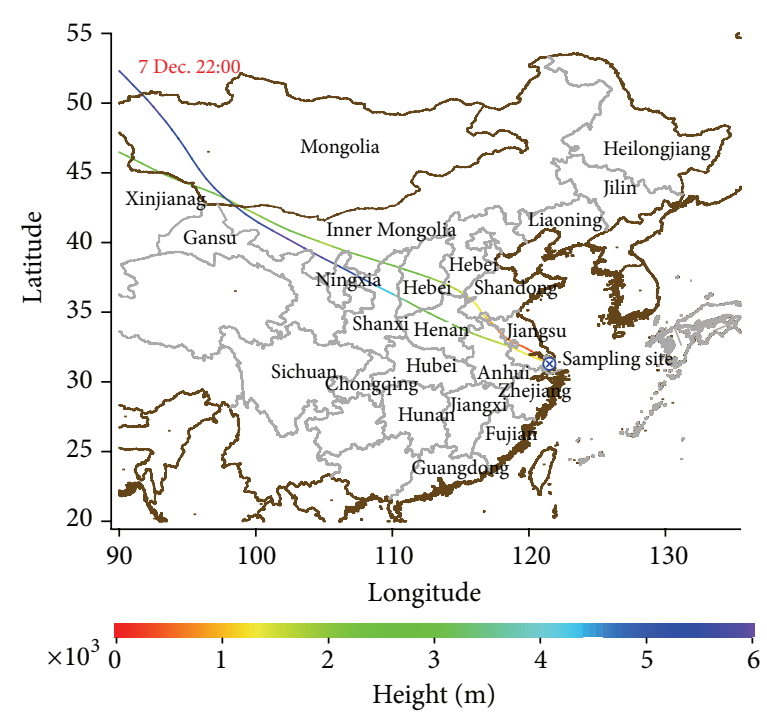

(b)

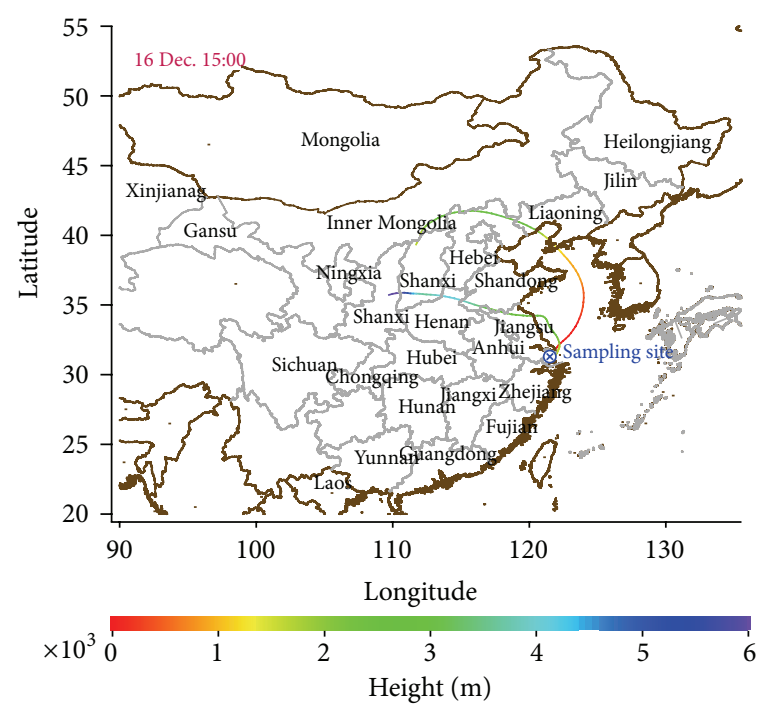

(d)

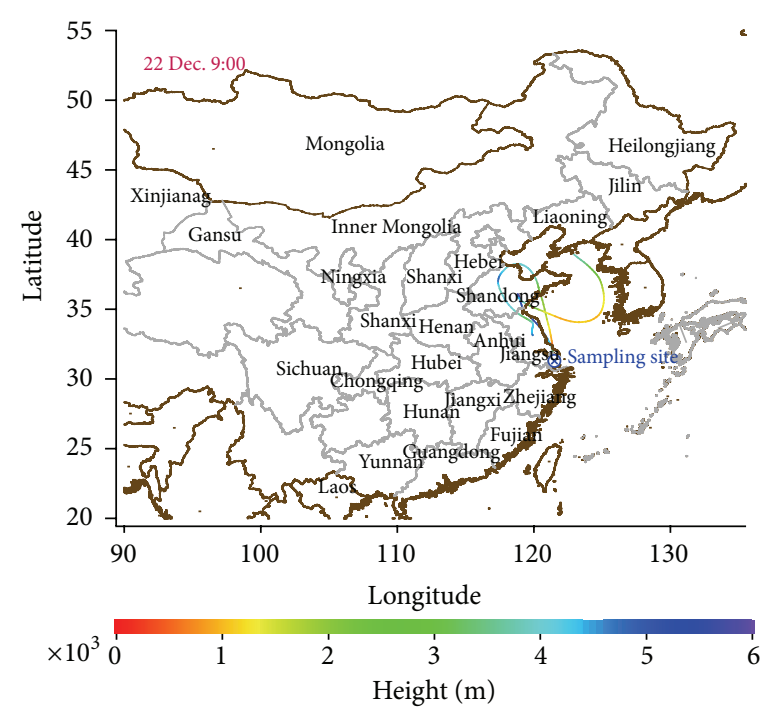

(f)

Figure 6: Continued. 


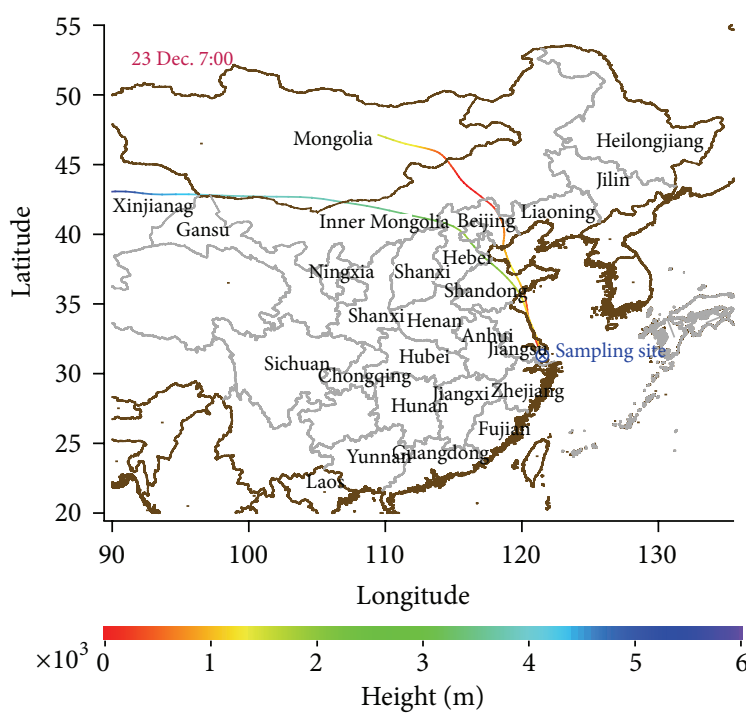

(g)

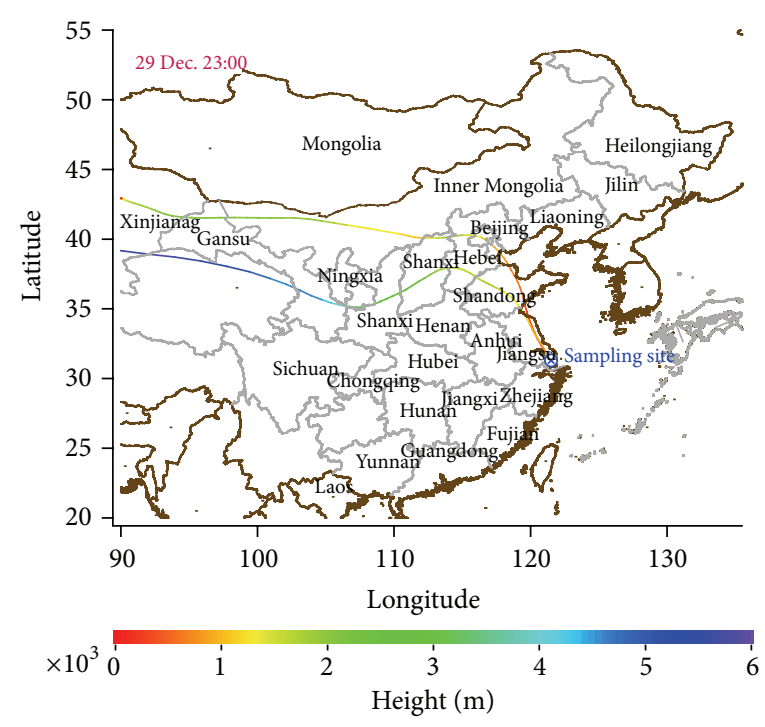

(h)

FIGURE 6: Air massbackward trajectories for 500- and 1000-meter altitude arriving in the measurement site at the very beginning of the haze periods (a) 3/12 at 12:00, (b) 7/12 at 22:00, (c) 14/12 at 12:00, (d) 16/12 at 15:00, (e) 21/12 at 09:00, (f) 22/12 at 09:00, (g) 23/12 at 07:00, and (h) 29/12 at 23:00.

Haze periods 2, 3, and 5 are accompanied by a high equimolar ratio of ammonium to the sum of sulfate and nitrate. The air masses arrive in Shanghai by passing over nearby ammonia rich areas (Figures 6(b), 6(c), and 6(e)). Haze periods 6, 7, and 8 are accompanied by lower equimolar ratio and air masses arrive in Shanghai from the North over the East China Sea (Figures 6(f), 6(g), and 6(h)). Air masses arriving in Shanghai before haze periods 1 and 4 come from the West and the NE going party over the East China Sea (Figures 6(a) and 6(d)).

Haze periods 2, 3, and 4 are accompanied by the highest absolute concentrations of ammonia (Table 2) and air masses arrived in Shanghai over nearby ammonia rich areas (Figure 1). Haze periods 6 and 7 are accompanied by high ammonium but relatively low ammonia concentrations indicating that ammonia is not the limiting factor in the aerosol formation. Air masses before this period enter Shanghai over the North Anhui and Shandong provinces.

\section{Conclusion}

From December 1 to 31 of 2012, 660 hourly samples of secondary inorganic aerosol species ammonium, sulfate, and nitrate together with precursor gasses ammonia, $\mathrm{SO}_{2}$, and $\mathrm{HNO}_{3}$ were obtained to study their role during visibility degradation in urban Shanghai. During the measurement period 8 haze episodes were identified (totaling 94 hours) based on a visibility $<10 \mathrm{~km}$ accompanied by an $\mathrm{RH}<90 \%$.

During the entire measurement period the sum of the SIA species in $\mathrm{PM}_{1}$ averaged $15.5 \pm 9.8 \mu \mathrm{g} / \mathrm{m}^{3}$ which accounted for $51.1 \pm 12.9 \%$ of the $\mathrm{PM}_{1}$ mass. Sulfate mass dominates (22.5\%), followed by nitrate (15.1\%) and ammonium (13.3\%). During haze the sum of SIA species show a similar trend as $\mathrm{PM}_{1}$ does and roughly doubles in mass concentrations.
An increase from an average of $14.9 \pm 7.4 \mu \mathrm{g} / \mathrm{m}^{3}$ during "clear" periods to $29.7 \pm 10.7 \mu \mathrm{g} / \mathrm{m}^{3}$ during the haze periods is observed for the sum of ammonium, sulfate, and nitrate. This means the mass contribution of SIA to $\mathrm{PM}_{1}$ during clear periods averaged $51.0 \pm 12.3 \%$ while the mass contribution during haze averaged $48.2 \pm 7.9 \%$.

To demonstrate the role of SIA species in the visibility degradation, correlations of visibility versus mass concentrations were studied. The correlation coefficients $\left(R^{2}\right)$ where the visibility is a function of the concentration showed values in the order of $\mathrm{PM}_{1}(0.56)>$ ammonium $(0.52)>$ sulfate $(0.41)>$ nitrate $(0.39)$. Correlation coefficients may be low, but figures demonstrate a negative exponential relation between increasing mass concentrations of $\mathrm{PM}_{1}$ solely and SIA mass concentrations in $\mathrm{PM}_{1}$ and visibility.

The molar equivalent ratio of ammonium versus the sum of sulfate and nitrate shows there is, on average, sufficient ammonium to neutralize sulfate and nitrate during the entire measurement periods and likely $\sim 5 \mathrm{~mol} \%$ ammonium is bound to chloride and bisulfate. The molar equivalent ratio of ammonium versus the sum of sulfate and nitrate increases from $1.05 \pm 0.11$ for clear weather periods to $1.10 \pm 0.08$ during haze episodes indicating there is more particulate ammonium than the sum of sulfate and nitrate during haze compared to clear weather. The elevated values can be explained by the formation of ammonium chloride. Correlation between the predicted ammonium (which is the sum of sulfate and nitrate: $\mathrm{NH}_{4}{ }^{+}$PRED $)$and the actual measured $\mathrm{NH}_{4}{ }^{+}\left(\mathrm{NH}_{4}{ }^{+}\right.$MEAS $)$for the entire study shows very good agreement between the values $\left(R^{2}=0.97\right)$ but overestimates $\mathrm{NH}_{4}^{+}$PRED by $\sim 12 \%$.

72-hour air mass backward trajectories for the haze periods are studied to see the long-distance impact of air pollutants on the visibility degradation. Air masses of two 
arrival altitudes, namely, 500 and 1000 meters, were computed. The air masses arrive in Shanghai by passing over nearby ammonia rich areas in the YRD where the air masses are injected with ammonia before they reach the site urban Shanghai. Different situations are encountered and ammonia ranged between 1.1 and $11.8 \mu \mathrm{g} / \mathrm{m}^{3}$ at the start of a haze period indicating the trajectories affect the mass concentrations of ammonia in urban Shanghai.

\section{Conflict of Interests}

The authors declare that there is no conflict of interests regarding the publication of this paper.

\section{Acknowledgments}

This work was supported by National Natural Science Foundation of China (no. 21190053), Shanghai Science and Technology Commission of Shanghai Municipality (13XD1400700, 12DJ1400100), and Priority fields for Ph.D. Programs Foundation of Ministry of Education of China (no. 20110071130003).

\section{References}

[1] M. J. Molina and L. T. Molina, "Megacities and atmospheric pollution," Journal of the Air and Waste Management Association, vol. 54, no. 6, pp. 644-680, 2004.

[2] J. H. Seinfeld and S. N. Pandis, Atmospheric Chemistry and Physics: From Air Pollution to Climate Change, John Wiley \& Sons, New York, NY, USA, 2006.

[3] L. Li, C. H. Chen, J. S. Fu et al., "Air quality and emissions in the Yangtze River Delta, China," Atmospheric Chemistry and Physics, vol. 11, no. 4, pp. 1621-1639, 2011.

[4] C. Huang, C. H. Chen, L. Li et al., "Emission inventory of anthropogenic air pollutants and VOC species in the Yangtze River Delta region, China," Atmospheric Chemistry and Physics, vol. 11, no. 9, pp. 4105-4120, 2011.

[5] T. J. Wang, F. Jiang, J. J. Deng et al., "Urban air quality and regional haze weather forecast for Yangtze River Delta region," Atmospheric Environment, vol. 58, pp. 70-83, 2012.

[6] L. M. Jin and J. Shi, "Climatic characteristics and change laws of fog and haze days in Shanghai," Plateau Meteorology, vol. 27, pp. 138-143, 2008.

[7] H. H. Du, L. D. Kong, T. T. Cheng et al., "Insights into summertime haze pollution events over Shanghai based on online water-soluble ionic composition of aerosols," Atmospheric Environment, vol. 45, no. 29, pp. 5131-5137, 2011.

[8] K. Huang, G. Zhuang, Y. Lin et al., "Typical types and formation mechanisms of haze in an Eastern Asia megacity, Shanghai," Atmospheric Chemistry and Physics, vol. 12, no. 1, pp. 105-124, 2012.

[9] G. Zhou, F. Yang, F. Geng, J. Xu, X. Yang, and X. Tie, "Measuring and modeling aerosol: relationship with haze events in Shanghai, China," Aerosol and Air Quality Research, vol. 14, pp. 783-792, 2014.

[10] C. K. Chan and X. Yao, "Air pollution in mega cities in China," Atmospheric Environment, vol. 42, no. 1, pp. 1-42, 2008.
[11] H. Che, X. Zhang, Y. Li, Z. Zhou, J. J. Qu, and X. Hao, "Haze trends over the capital cities of 31 provinces in China, 19812005," Theoretical and Applied Climatology, vol. 97, no. 3-4, pp. 235-242, 2009.

[12] D. Chang, Y. Song, and B. Liu, "Visibility trends in six megacities in China 1973-2007," Atmospheric Research, vol. 94, no. 2, pp. 161-167, 2009.

[13] D. Jacob, Introduction to Atmospheric Chemistry, Princeton Univerisyt Press, 1999.

[14] J. L. Jimenez, M. R. Canagaratna, N. M. Donahue et al., "Evolution of organic aerosols in the atmosphere," Science, vol. 326, no. 5959, pp. 1525-1529, 2009.

[15] X. F. Huang, L. Y. He, L. Xue et al., "Highly time-resolved chemical characterization of atmospheric fine particles during 2010 Shanghai World Expo," Atmospheric Chemistry and Physics, vol. 12, no. 11, pp. 4897-4907, 2012.

[16] R. J. Charlson, J. Langner, H. Rodhe, C. B. Leovy, and S. G. Warren, "Perturbation of the Northern Hemisphere radiative balance by backscattering from anthropogenic sulfate aerosols," Tellus A, vol. 43, no. 4, pp. 152-163, 1991.

[17] R. J. Charlson, S. E. Schwartz, J. M. Hales et al., "Climate forcing by anthropogenic aerosols," Science, vol. 255, no. 5043, pp. 423430, 1992.

[18] J. F. Sisler and W. C. Malm, "The relative importance of soluble aerosols to spatial and seasonal trends of impaired visibility in the United States," Atmospheric Environment, vol. 28, no. 5, pp. 851-862, 1994.

[19] H. M. T. Brink, J. P. Veefkind, A. Waijers-Ijpelaan, and J. C. van der Hage, "Aerosol light-scattering in the Netherlands," Atmospheric Environment, vol. 30, no. 24, pp. 4251-4261, 1996.

[20] W. C. Malm and D. E. Day, "Estimates of aerosol species scattering characteristics as a function of relative humidity," Atmospheric Environment, vol. 35, no. 16, pp. 2845-2860, 2001.

[21] Y. L. Lee and R. Sequeira, "Water-soluble aerosol and visibility degradation in Hong Kong during autumn and early winter, 1998," Environmental Pollution, vol. 116, no. 2, pp. 225-233, 2002.

[22] C. M. Kang, H. S. Lee, B. W. Kang, S. K. Lee, and Y. Sunwoo, "Chemical characteristics of acidic gas pollutants and $\mathrm{PM}_{2.5}$ species during hazy episodes in Seoul, South Korea," Atmospheric Environment, vol. 38, no. 28, pp. 4749-4760, 2004.

[23] K. W. Kim, Y. J. Kim, and S. Y. Bang, "Summer time haze characteristics of the urban atmosphere of Gwangju and the rural atmosphere of Anmyon, Korea," Environmental Monitoring and Assessment, vol. 141, no. 1-3, pp. 189-199, 2008.

[24] F. Wang, D. S. Chen, S. Y. Cheng, J. B. Li, M. J. Li, and Z. H. Ren, "Identification of regional atmospheric $\mathrm{PM}_{10}$ transport pathways using HYSPLIT, MM5-CMAQ and synoptic pressure pattern analysis," Environmental Modelling and Software, vol. 25, no. 8, pp. 927-934, 2010.

[25] W. C. Malm, J. F. Sisler, D. Huffman, R. A. Eldred, and T. A. Cahill, "Spatial and seasonal trends in particle concentration and optical extinction in the United States," Journal of Geophysical Research, vol. 99, no. 1, pp. 1347-1370, 1994.

[26] D. W. Byun and J. K. S. Ching, "Science algorithms of the EPA Models-3 community multi-scale air quality (CMAQ) modeling system," Tech. Rep. EPA/600/R-99/030, Office of Research and Development, U.S. EPA, Research Triangle Park, NC, USA, 1999.

[27] J. F. Sisler and W. C. Malm, "Interpretation of trends of $\mathrm{PM}_{2.5}$ and reconstructed visibility from the IMPROVE network," Journal of the Air and Waste Management Association, vol. 50, no. 5, pp. 775-789, 2000. 
[28] L. T. Wang, J. Xu, J. Yang et al., "Understanding haze pollution over the southern Hebei area of China using the CMAQ model," Atmospheric Environment, vol. 56, pp. 69-79, 2012.

[29] D. Byun and K. L. Schere, "Review of the governing equations, computational algorithms, and other components of the models-3 Community Multiscale Air Quality (CMAQ) modeling system," Applied Mechanics Reviews, vol. 59, no. 1-6, pp. 51-76, 2006.

[30] M. Zhang, Z. Han, and L. Zhu, "Simulation of atmospheric aerosols in East Asia using modeling system RAMS-CMAQ: model evaluation," China Particuology, vol. 5, no. 5, pp. 321-327, 2007.

[31] I. Uno, Y. He, T. Ohara et al., "Systematic analysis of interannual and seasonal variations of model-simulated tropospheric $\mathrm{NO}_{2}$ in Asia and comparison with GOME-satellite data," Atmospheric Chemistry and Physics, vol. 7, no. 6, pp. 1671-1681, 2007.

[32] Q. Y. Fu, G. S. Zhuang, J. Wang et al., "Mechanism of formation of the heaviest pollution episode ever recorded in the Yangtze River Delta, China," Atmospheric Environment, vol. 42, no. 9, pp. 2023-2036, 2008.

[33] X. Liu, Y. Zhang, S. Cheng et al., "Understanding of regional air pollution over China using CMAQ, part I performance evaluation and seasonal variation," Atmospheric Environment, vol. 44, no. 20, pp. 2415-2426, 2010.

[34] X. Liu, Y. Zhang, J. Xing et al., "Understanding of regional air pollution over China using CMAQ, part II. Process analysis and sensitivity of ozone and particulate matter to precursor emissions," Atmospheric Environment, vol. 44, no. 30, pp. 37193727, 2010.

[35] W. A. H. Asman, M. A. Sutton, and J. K. Schjørring, "Ammonia: emission, atmospheric transport and deposition," New Phytologist, vol. 139, no. 1, pp. 27-48, 1998.

[36] J. Kirkby, J. Curtius, J. Almeida et al., "Role of sulphuric acid, ammonia and galactic cosmic rays in atmospheric aerosol nucleation," Nature, vol. 476, no. 7361, pp. 429-435, 2011.

[37] E. Nemitz, M. A. Sutton, D. Fowler, and T. W. Choularton, "Application of a $\mathrm{NH}_{3}$ gas-to-particle conversion model to measurement data," in Atmospheric Ammonia: Emission, Deposition and Environmental Impacts. Poster Proceedings of the International Conference on Atmospheric Ammonia (Culham, Oxford, UK, 2-4 October 1995), M. A. Sutton, D. S. Lee, G. J. Dollard, and D. Fowler, Eds., pp. 98-103, Institute of Terrestrial Ecology, Edinburg, UK, 1996.

[38] J. J. Huntzicker, R. A. Cary, and C. S. Ling, "Neutralization of sulfuric acid aerosol by ammonia," Environmental Science and Technology, vol. 14, no. 7, pp. 819-824, 1980.

[39] P. H. McMurry, H. Takano, and G. R. Anderson, "Study of the ammonia (gas)-sulfuric acid (aerosol) reaction rate," Environmental Science and Technology, vol. 17, no. 6, pp. 347$352,1983$.

[40] R. M. Harrison and A. N. Kitto, "Estimation of the rate constant for the reaction of acid sulphate aerosol with $\mathrm{NH}_{3}$ gas from atmospheric measurements," Journal of Atmospheric Chemistry, vol. 15, no. 2, pp. 133-143, 1992.

[41] P. Warneck, Chemistry of the Natural Atmosphere, vol. 71, Acedemic Press, New York, NY, USA, 2nd edition, 2000.

[42] R. K. Pathak, W. S. Wu, and T. Wang, "Summertime $\mathrm{PM}_{2.5}$ ionic species in four major cities of China: nitrate formation in an ammonia-deficient atmosphere," Atmospheric Chemistry and Physics, vol. 9, no. 5, pp. 1711-1722, 2009.

[43] A. W. Stelson and J. H. Seinfeld, "Relative humidity and temperature dependence of the ammonium nitrate dissociation constant," Atmospheric Environment, vol. 16, no. 5, pp. 983-992, 1982.

[44] C. A. Pio and R. M. Harrison, "The equilibrium of ammonium chloride aerosol with gaseous hydrochloric acid and ammonia under tropospheric conditions," Atmospheric Environment, vol. 21, no. 5, pp. 1243-1246, 1987.

[45] J. W. Erisman and M. Schaap, "The need for ammonia abatement with respect to secondary PM reductions in Europe," Environmental Pollution, vol. 129, no. 1, pp. 159-163, 2004.

[46] R. J. Barthelmie and S. C. Pryor, "Implications of ammonia emissions for fine aerosol formation and visibility impairment-a case study from the Lower Fraser Valley, British Columbia," Atmospheric Environment, vol. 32, no. 3, pp. 345-352, 1998.

[47] X. Ye, Z. Ma, J. Zhang et al., "Important role of ammonia on haze formation in Shanghai," Environmental Research Letters, vol. 6, no. 2, Article ID 024019, 2011.

[48] R. R. Draxler and G. D. Rolph, HYSPLIT-Hybrid Single Particle Lagrangian Integrated Trajectory Model, NOAA Air Resources Laboratory, Silver Spring, Md, USA, 2003, http://ready.arl.noaa.gov/HYSPLIT.php.

[49] R. R. Draxler and G. D. Hess, "An overview of the HYSPLIT_4 modelling system for trajectories, dispersion and deposition," Australian Meteorological Magazine, vol. 47, no. 4, pp. 295-308, 1998.

[50] G. P. Wyers, R. P. Otjes, and J. Slanina, "A continuous-flow denuder for the measurement of ambient concentrations and surface-exchange fluxes of ammonia," Atmospheric Environment A: General Topics, vol. 27, no. 13, pp. 2085-2090, 1993.

[51] A. Khlystov, G. P. Wyers, and J. Slanina, "The steam-jet aerosol collector," Atmospheric Environment, vol. 29, no. 17, pp. 22292234, 1995.

[52] J. Slanina, H. M. Ten Brink, R. P. Otjes et al., "The continuous analysis of nitrate and ammonium in aerosols by the steam jet aerosol collector (SJAC): extension and validation of the methodology," Atmospheric Environment, vol. 35, no. 13, pp. 2319-2330, 2001.

[53] U. Makkonen, A. Virkkula, J. Mäntykenttä et al., "Semicontinuous gas and inorganic aerosol measurements at a Finnish urban site: comparisons with filters, nitrogen in aerosol and gas phases, and aerosol acidity," Atmospheric Chemistry and Physics, vol. 12, no. 12, pp. 5617-5631, 2012.

[54] A. Sorooshian, F. J. Brechtel, Y. L. Ma et al., "Modeling and characterization of a particle-into-liquid sampler (PILS)," Aerosol Science and Technology, vol. 40, no. 6, pp. 396-409, 2006.

[55] I. Trebs, F. X. Meixner, J. Slanina, R. Otjes, P. Jongejan, and M. O. Andreae, "Real-time measurements of ammonia, acidic trace gases and water-soluble inorganic aerosol species at a rural site in the Amazon Basin," Atmospheric Chemistry and Physics, vol. 4, no. 4, pp. 967-987, 2004.

[56] Y. J. Yang, J. G. Tan, Y. F. Zheng, and S. H. Cheng, "Study on the atmospheric stabilities and the thickness of atmospheric mixed layer during recent 15 years in Shanghai," Scientia Meteorologica Sinica, vol. 26, pp. 536-541, 2006.

[57] L. Kong, Y. Yang, S. Zhang et al., "Observations of linear dependence between sulfate and nitrate in atmospheric particles," Journal of Geophysical Research: Atmospheres, vol. 119, pp. 341361, 2014.

[58] D. Wu, X. Tie, C. Li et al., "An extremely low visibility event over the Guangzhou region: a case study," Atmospheric Environment, vol. 39, no. 35, pp. 6568-6577, 2005. 
[59] Z. M. Xiao, Y. F. Zhang, S. M. Hong et al., "Estimation of the main factors influencing haze, based on a long-term monitoring campaign in Hangzhou, China," Aerosol and Air Quality Research, vol. 11, no. 7, pp. 873-882, 2011.

[60] K. He, Q. Zhao, Y. Ma et al., "Spatial and seasonal variability of $\mathrm{PM}_{2.5}$ acidity at two Chinese megacities: insights into the formation of secondary inorganic aerosols," Atmospheric Chemistry and Physics, vol. 12, no. 3, pp. 1377-1395, 2012.

[61] A. Sorooshian, S. M. Murphy, S. Hersey et al., "Comprehensive airborne characterization of aerosol from a major bovine source," Atmospheric Chemistry and Physics, vol. 8, no. 17, pp. 5489-5520, 2008.

[62] M. Lin, J. Walker, C. Geron, and A. Khlystov, "Organic nitrogen in $\mathrm{PM}_{2.5}$ aerosol at a forest site in the Southeast US," Atmospheric Chemistry and Physics, vol. 10, no. 5, pp. 2145-2157, 2010. 

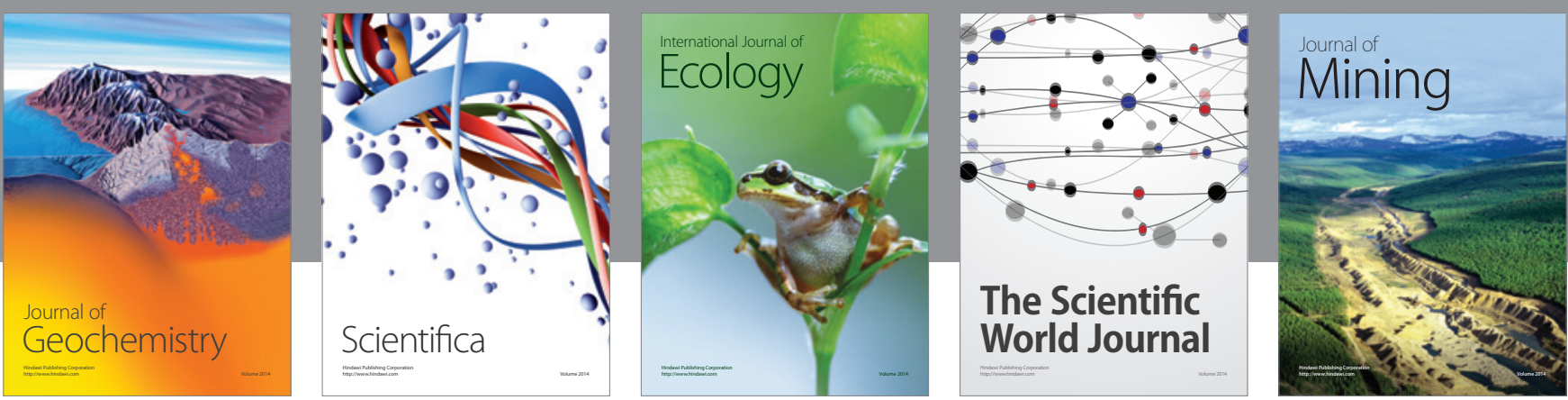

The Scientific World Journal
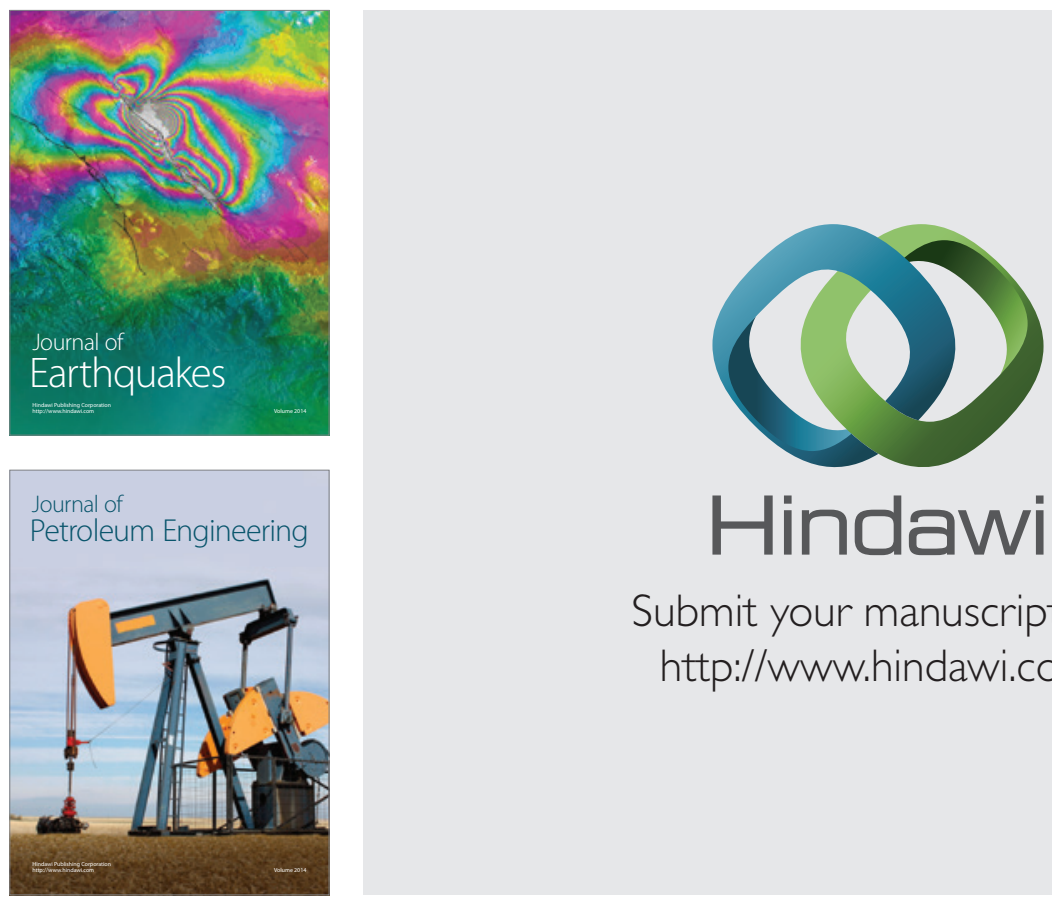

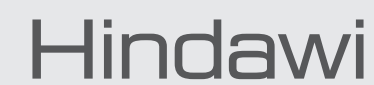

Submit your manuscripts at

http://www.hindawi.com
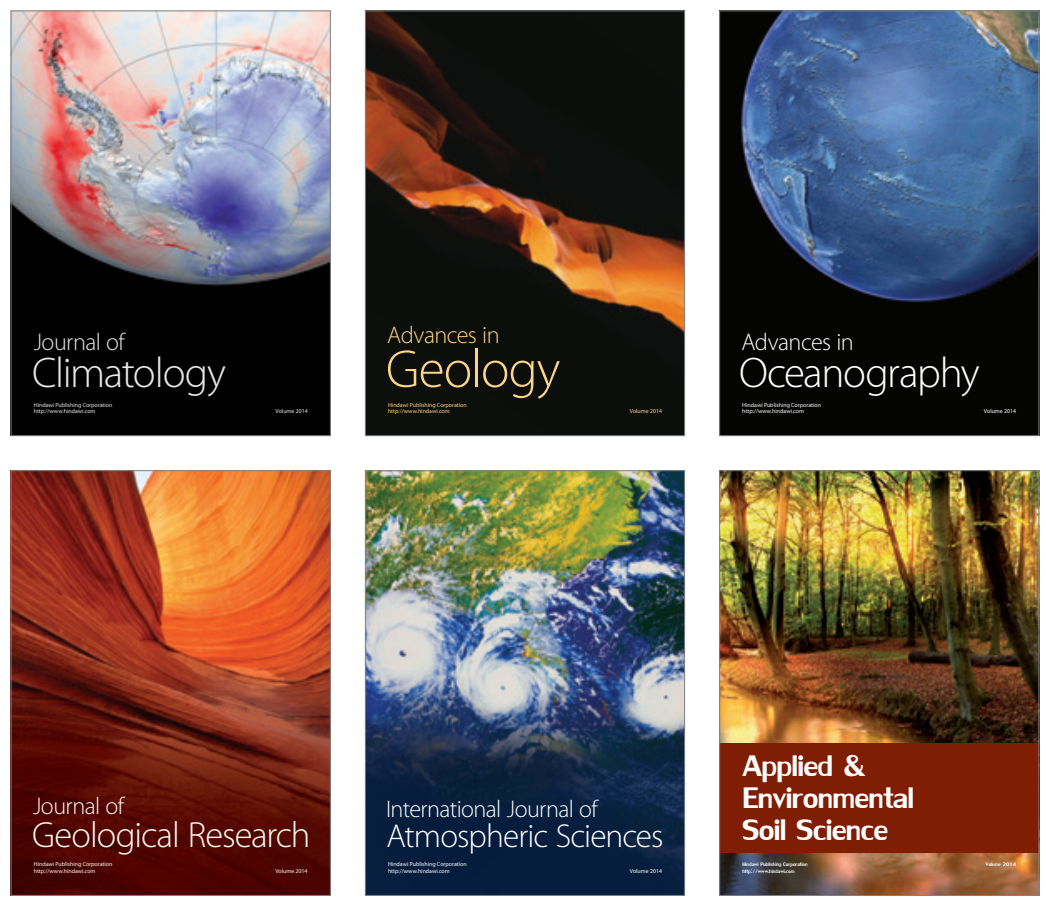
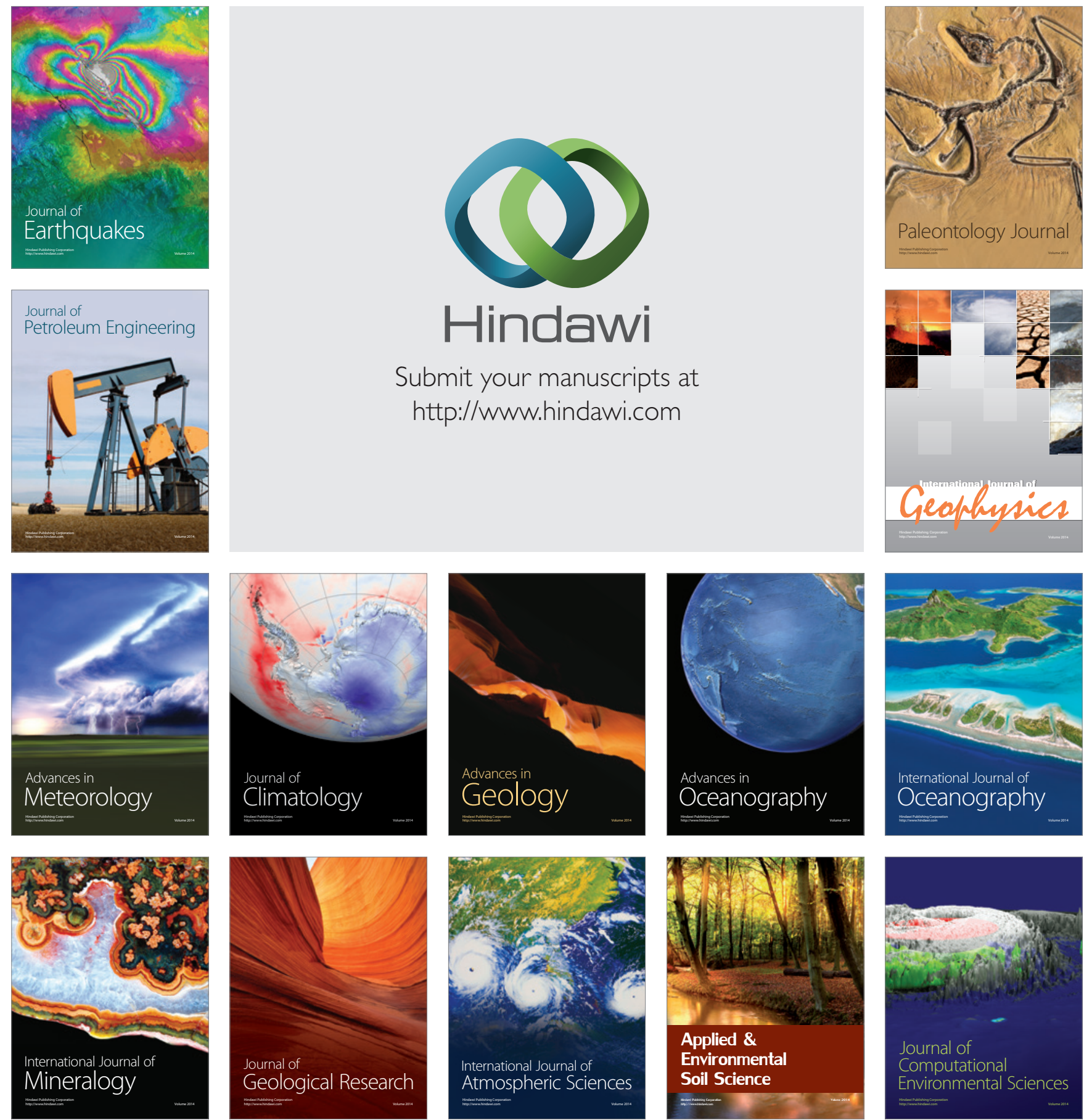